\title{
Stimulation of the Lipoxygenase Pathway Is Associated with Systemic Resistance Induced in Bean by a Nonpathogenic Pseudomonas Strain
}

\author{
Marc Ongena, ${ }^{1}$ Francéline Duby, ${ }^{2}$ Fanny Rossignol, ${ }^{1}$ Marie-Laure Fauconnier, ${ }^{3}$ Jacques Dommes, ${ }^{2}$ \\ and Philippe Thonart ${ }^{1}$ \\ ${ }^{1}$ Centre Wallon de Biologie Industrielle, Université de Liège and Faculté Universitaire des Sciences Agronomiques de \\ Gembloux, Belgium; ${ }^{2}$ Laboratoire de Biologie Moléculaire Végétale, Université de Liège, Belgium; ${ }^{3}$ Unité de Chimie \\ Générale et Organique, Faculté Universitaire des Sciences Agronomiques de Gembloux, Belgium
}

Submitted 29 December 2003. Accepted 7 May 2004.

Systemic defense reactions induced in bean by the nonpathogenic Pseudomonas putida BTP1 strain reduced disease caused by Botrytis cinerea. Phenylalanine ammonialyase activity and the level of endogenous free salicylic acid were compared in plant growth-promoting rhizobacteriatreated versus control plants, but no significant differences were detected. Furthermore, no enhanced fungitoxicity was detected in methanolic leaf extracts, suggesting that accumulation of bean phytoalexins was not part of the stimulated defense mechanisms. However, BTP1-inoculated plants showed increased levels of both linoleic and linolenic acids. On this basis, we further investigated whether the lipoxygenase pathway, leading to antifungal phytooxylipins, could have been stimulated. Two key enzymatic activities of this metabolic route, namely lipoxygenase and hydroperoxide lyase, were significantly stimulated during the first four days after challenging BTP1-treated plants with the pathogen. This was observed in parallel with a more rapid consumption of the respective substrates of these enzymes, as revealed by measurements of endogenous concentrations of linolenic acid and their hydroperoxide derivatives. Moreover, headspace-gas chromatography analyses showed significantly higher concentrations of the fungitoxic final product Z-3-hexenal in leaves from BTP1-inoculated beans as compared with control plants. Taken together, these results strongly suggest that the oxylipin pathway can be associated with enhanced disease resistance induced in bean plants by nonpathogenic rhizobacteria.

Additional keyword: plant protection.

Some rhizobacteria can exert their beneficial effect on plant growth indirectly by disease suppression. Niche exclusion, competition for nutrients, siderophore-mediated competition for iron, antibiosis, and production of extracellular enzymes have been described as mechanisms involved in the disease reduction mediated by rhizobacteria (Ramamoorthy et al. 2001; Whipps 2001). Beside these direct antagonistic mechanisms, some plant growth-promoting rhizobacteria (PGPR) are also able to reduce disease through the stimulation of inducible plant defense mechanisms that render the host more resistant to further pathogen ingress. Induction of such enhanced defensive capacity can

Corresponding author: M. Ongena; Telephone: +32 4 3663997; Fax: +32 4 3662861; E-mail: ongena.m@fsagx.ac.be be systemic, as root treatment with a PGPR was shown to trigger protective effects on above-ground plant parts. These reactions typically result from the activation of latent defense mechanisms that are overexpressed upon subsequent pathogen challenge (Van Loon et al. 1998). Rhizobacteria-mediated induced systemic resistance (ISR) (Kloepper et al. 1992) can occur in many plant species and was demonstrated to be effective for the control of a broad range of fungal, bacterial, and viral diseases but also against some insect and nematode pests (Van Loon et al. 1998). As the phenomenon is long-lasting and does not require extensive root colonization by the inducing microbe, ISR-based biocontrol strategies are promising, and some trials were successfully performed under field conditions (Wei et al. 1996; Zehnder et al. 2001).

ISR is phenotypically similar to the well-studied systemic acquired resistance (SAR) activated after a first infection by an incompatible necrotizing pathogen (Hammerschmidt 1999a; Sticher et al. 1997). However, the signal transduction pathway and the molecular basis underlying the rhizobacteria-mediated ISR differ in many aspects from the pathogen-induced SAR. Extensive work on Arabidopsis thaliana has demonstrated the dependence of ISR signal transduction on the perception of plant hormones such as jasmonate and ethylene (Pieterse et al. 2001; Ton et al. 2002), in contrast with SAR, which is characterized by an early increase in endogenously synthesized salicylic acid (SA) (Glazebrook et al. 2003; Métraux 2001). In some cases, however, enhanced levels of SA were detected in plants following treatment with PGPR. Beside SA, accumulation of pathogenesis-related (PR) proteins is also commonly associated with the expression of SAR (Van Loon and Van Strien 1999), but this phenomenon can obviously not be considered as a marker for ISR. Attempts to associate rhizobacteria-induced ISR with PR protein accumulation led to contradictory results. For instance, Maurhofer and associates (1994) showed that ISR induced by $P$. fluorescens $\mathrm{CHAO}$ in tobacco is coupled with stimulation of PR protein synthesis, while Hoffland (1995) and Pieterse (1996) and their associates reported that such proteins did not accumulate in radish or $A$. thaliana expressing PGPR-mediated ISR, respectively. Again, in the case of SAR, several well-characterized defense reactions, such as hypersensitive reaction (HR) (Kombrink and Schnelzer 2001), oxidative burst (Lamb and Dixon 1997), reinforcement of cell wall structures through lignification or callose deposition (Benhamou and Nicole 1999), accumulation of antimicrobial phytoalexins (Hammerschmidt 1999b; Kùc 1995), and induction of defense-related proteins with antifun- 
gal properties (Linthorst 1991; Xue et al. 1998) have been extensively reported in many plant species. By contrast, protective mechanisms involved in ISR are just beginning to be elucidated. To our knowledge, HR has not yet been related to PGPR-induced resistance, and the stimulation of plant phytoalexin synthesis was only reported in Pseudomonas-inoculated carnation (Van Peer et al. 1991) and cucumber (Ongena et al. 2000). Only a few reports described the induction of defensive physical barriers to pathogen ingress following preinoculation with PGPR (Benhamou et al. 1996, 2000).

We have previously reported the ISR-mediated protective effect of Pseudomonas putida BTP1 strain on cucumber against root rot caused by Pythium aphanidermatum (Ongena et al. 1999). Further studies revealed that the disease protective effect was associated with a systemic increase of fungitoxic phenolics that could be considered as phytoalexins on the basis of their accumulation pattern (Ongena et al. 2000). In a recent study, we demonstrated that the same strain was also effective at reducing disease incidence caused by Botrytis cinerea on bean plants (Ongena et al. 2002a). Preliminary analyses of leaf extracts from bean plants treated with BTP1 revealed higher amounts of linolenic and linoleic acids as compared with control plants (M. Ongena, unpublished data). These polyunsaturated fatty acids serve as substrates for the lipoxygenase (LOX; EC 1.13.11.12) enzyme that initiates a metabolic route leading to the synthesis of various antifungal compounds involved in plant defenses (Blée 2002). More generally, this LOX pathway can be stimulated under different stress conditions, such as mechanical damage (Conconi et al. 1996), in response to treatment with SA (Weichert et al. 1999), methyl jasmonate (Avdiushko et al. 1995; Kohlmann et al. 1999), or biotic elicitors (Rustérucci et al. 1999) but also following interactions with pathogens (Croft et al. 1993; Montillet et al. 2002; Rancé et al. 1998). The regioselective and stereoselective dioxygenation of linoleic or linolenic acids through the LOX activity leads to the formation of the corresponding HPODE (hydroperoxy-octadecatrienoic acid) and HPOTE (hydroperoxy-octadecadienoic acid) derivatives. These highly reactive LOX products are subsequently transformed into a series of phyto-oxylipins via multiple well-characterized metabolic routes, such as i) the peroxygenase (POX) pathway leading to the conversion to fungitoxic epoxy- and hydroxy-derivatives; ii) the allene oxide synthase (AOS)

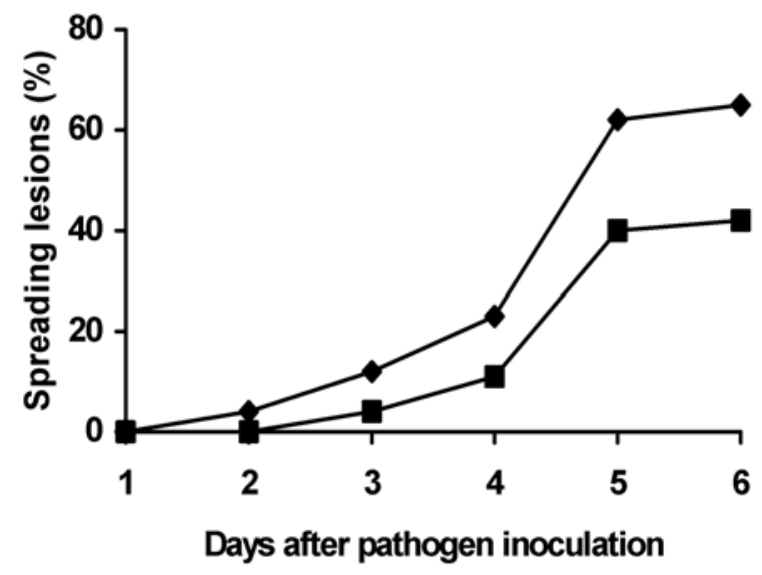

Fig. 1. Evolution of disease severity in control ( ) and BTP1-treated bean plants (ם), after infection with Botrytis cinerea. Plants were inoculated on each primary leaf with eight $7-\mu$ l drops of a suspension $\left(5 \times 10^{6}\right.$ spores per $\mathrm{ml}$ ) of the pathogen. Disease incidence was scored daily and was expressed in terms of the percentage of $B$. cinerea spreading lesions. Data are from one representative experiment realized with 25 plants per treatment. leading to the production of jasmonates known to be involved in signaling events and regulation of plant defensegene expression; iii) the hydroperoxide lyase (HPL) forming short chain aldehydes that are believed to behave as "volatile phytoalexins", and iv) the divinyl ether synthase (DES), which has been detected only in the Solanaceae (Blée 1998, 2002; Feussner and Wasternack 2002).

This work aims to further characterize the defense mechanisms that could contribute to the enhanced level of resistance observed in bean upon treatment with strain BTP1. First, we studied some of the key enzyme activities of the LOX pathway, and the concentrations of both substrates and products were determined in order to evaluate their potential activation following treatment with strain BTP1. Special emphasis was also devoted to the analysis of volatile end-products generated by the HPL branch of this metabolism. Secondly, the possible involvement of some features commonly associated with SAR or ISR was evaluated by determining whether i) enhanced resistance triggered by BTP1 could be SA-dependent, ii) phenylalanine ammonia-lyase (PAL; EC 4.3.1.5.) activity initiating the synthesis of lignin monomers and precursors of isoflavonoid-derived phytoalexins in bean (Dixon et al. 2002) could be stimulated, and iii) accumulation of antifungal compounds in bean plant tissues could be involved.

\section{RESULTS}

Disease reduction by treatment with $P$. putida BTP1.

Botrytis cinerea infection from inoculation droplets containing spore suspension at $5 \times 10^{6}$ spores per ml typically resulted in brownish, spreading lesions colonizing the whole leaf area. Disease incidence was thus expressed in terms of the percentage of $B$. cinerea lesions that clearly grew out of the inoculum drop zone to produce spreading lesions. Pooled data from four independent experiments (homogeneity of variances tested by analysis of variance [ANOVA]; interactions between experiment and treatment not significant at $P=0.05$ ) showed a statistically significant $34 \%$ disease reduction $(\alpha=0.05)$ in plants preinoculated at the root level with $P$. putida BTP1, as compared with the challenged controls. Figure 1 illustrates the time course of disease development in one representative experiment with disease symptoms that clearly appeared three days after pathogen challenge. As a previous study showed that the PGPR and the pathogen remained spatially separated (Ongena et al. 2002a), disease suppression was undoubtedly due to induction of resistance in the host plant.

\section{Stimulation of lipoxygenase activity in PGPR-treated plants.}

To evaluate the potential effect of BTP1 treatment on the LOX pathway, differential accumulation of linolenic and linoleic acids in infected leaf tissues was examined in three independent experiments at various times before and after pathogen challenge. Total linolenic and linoleic acids were quantified in their methylated form by gas chromatography. We observed that the C18:3 acid was the major form present in leaves, with amounts 10 times greater than those measured for the C18:2 linoleic acid (Fig. 2A and B). This reflects the ratio commonly found in leaf tissues (Montillet et al. 2002; Weichert et al. 1999) and suggests the involvement of a putative 13LOX in bean plants, as it was previously reported (Croft et al. 1993).

Interestingly, analyses revealed twofold higher concentrations for both substrates in plants treated with the bacteria, compared with controls before pathogen inoculation. In addition, infection by $B$. cinerea resulted in a more marked decrease of fatty acid amounts in BTP1-treated leaves than in 
controls during the first $48 \mathrm{~h}$ (Fig. 2A and B). This differential consumption could be related to significant increases (fourfold) in the activity of the first key enzyme of this pathway, i.e., LOX, during the same period in treated bean plants compared with controls (Fig. 2C). Starting from $48 \mathrm{~h}$ after pathogen challenge, LOX activity in resistant plants decreased to reach values similar to those measured in controls 5 days postinfection. This was associated with some recovery of the fatty acid concentrations during the same period.

\section{Induction of lipid hydroperoxidase activity.}

LOX introduces molecular oxygen to unsaturated linolenic and linoleic acids to yield either 9- or 13-hydroperoxides that can in turn be used by various enzymes to generate a wide variety of biologically active secondary metabolites. This global activity of all hydroperoxide-degrading enzymes is expressed as lipid hydroperoxidase activity (LHP). To further characterize the bean response, accumulation of LOX products and LHP activity were monitored. As expected on the basis of relative concentrations of linolenic and linoleic acids in leaf tissues, reversed-phase high-performance liquid chromatography (HPLC) analyses of hydroperoxides showed that HPOTE deriving from linolenic acid were prevalent. They represented more than $80 \%$ of the total lipid peroxides extracted from infected leaves in both elicited and control plants (data not shown). These analyses also revealed that the 13isomers were largely predominant, representing up to $90 \%$ of the total HPOTE. This suggested that 13-LOX is the predominant specific activity in the leaves of bean plants, and we have therefore limited our subsequent study to the quantification of 13-HPOTE. Probably due to enhanced LOX activity in the corresponding tissues, mean values for 13-HPOTE concentrations in plants inoculated with the PGPR were about 1.7-fold higher than in water-treated controls before infection (Fig. 3A). However, as observed for fatty acids, hydroperoxide concentrations in leaves from BTP1-treated beans markedly decreased following pathogen inoculation, to reach values significantly lower than those measured in control plants 3 days after infection. These data suggested a higher consumption rate of hydroperoxides in PGPR-treated plants initiated by the perception of the pathogen.

Evolution of LHP activity was monitored by measuring fatty acid hydroperoxide-cleaving activity in leaf extracts. Prior to pathogen challenge, LHP activity in plants colonized by BTP1 was similar to that observed in noninoculated plants. However, a rapid stimulation of LHP (1.5-fold) was specifically observed in BTP1-treated plants during the first $24 \mathrm{~h}$ after infection (Fig. 3B). This higher LHP activity was maintained in elicited plants for $72 \mathrm{~h}$. Moreover, LHP activities were also measured in extracts prepared from noninfected leaves collected in two separate experiments one day after pathogen challenge. As in infected tissues, higher LHP activities were observed in plants treated with the bacteria compared with controls with mean values (calculated from four measurements in extracts from each experiment) of $2,455 \pm 124 \mathrm{mU}$ per $\mathrm{g}$ of fresh weight (FW) and 1,632 $\pm 95 \mathrm{mU}$ per $\mathrm{g}$ of $\mathrm{FW}$, respectively. These data suggested that the transient induction of LHP in BTP1-treated plants was systemic and not restricted to infected organs.

\section{Hydroperoxide lyase}

as the main 13-HPOTE-degrading activity in bean leaves.

To further study the fate of fatty acid hydroperoxides and the specificity of ensuing reactions, LHP extracts of infected leaf tissues from both BTP1-treated and control plants were analyzed for the specific production of volatile aldehydes or their associated alcohols. Volatile aldehydes produced from 13-HPOTE over a period of 5 min were identified and quanti-

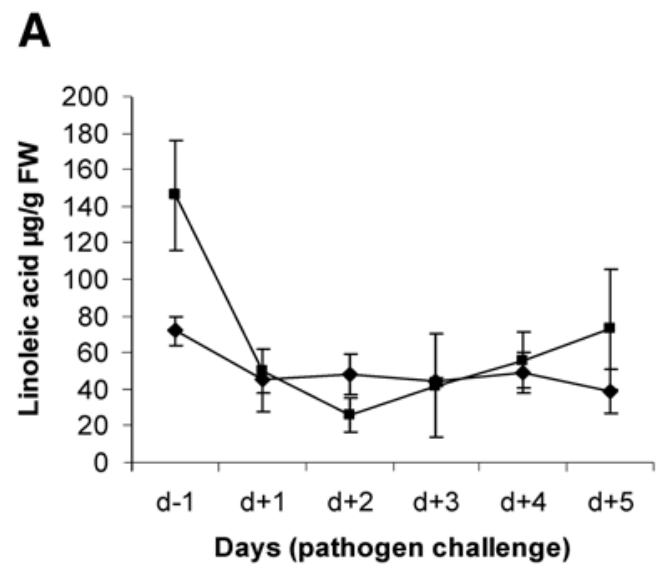

B
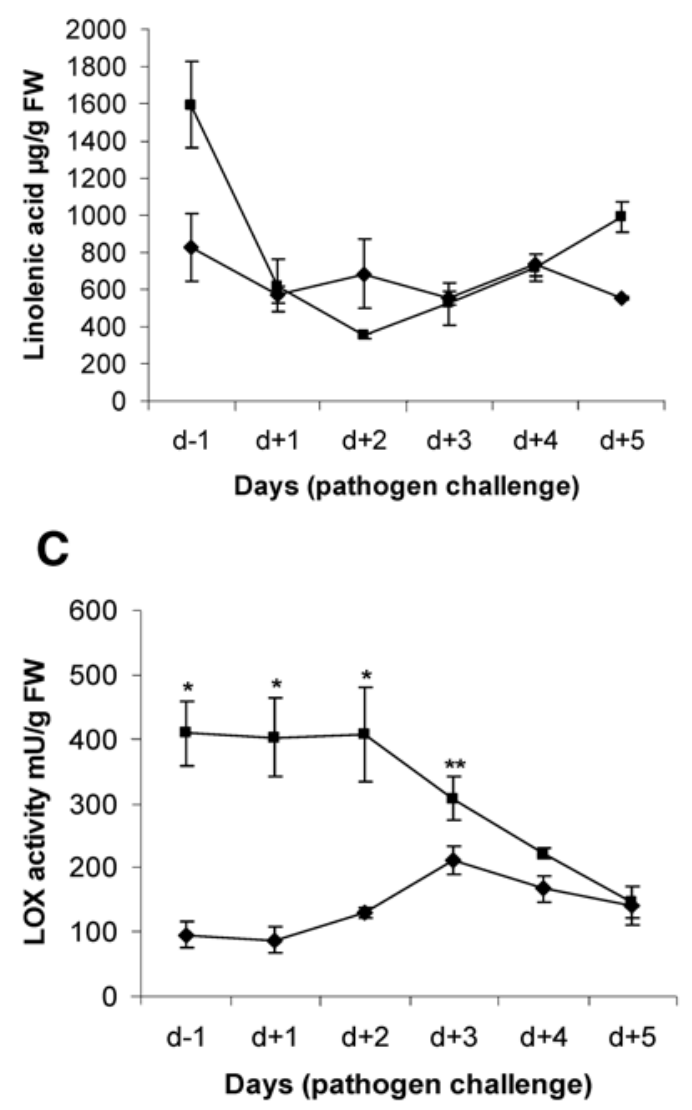

Fig. 2. Time course of lipoxygenase activity (LOX) and fatty acid substrate concentrations in bean plants previously treated with Pseudomonas putida BTP1 ( $\mathbf{a})$ and in control plants $(\bullet)$. Extracts were prepared from the first true leaves collected just before inoculation of the pathogen $(\mathrm{d}-1)$ and $24(\mathrm{~d}+1), 48(\mathrm{~d}+2), 72(\mathrm{~d}+3), 96(\mathrm{~d}+4)$, and $120 \mathrm{~h}$ $(d+5)$ after challenge. A, Concentrations of endogenous linoleic acid and B, linolenic acid were determined by gas chromatography after extraction with chloroform and methylation with boron trifluoride. Data are means and standard deviations calculated from three measurements performed at every sampling time in three independent experiments. C, LOX activities were determined on the basis of substrate consumption by enzyme extracts prepared from leaf material used for endogenous fatty acids analyses. Data are means and standard errors of four independent experiments with three measurements performed on leaf material collected at every sampling time in every experiment. Data were normally distributed and the homogeneity of variances was verified according to the Levene's test $(P=0.05)$. $*$ and $* *$ indicate significant differences $(\alpha=$ 0.001 and 0.01 , respectively) in LOX activity between controls and BTP1treated plants at a specific timepoint, as revealed by pair-wise comparison of means with the Fisher's least significant difference test. 
fied by headspace-gas chromatography (HS-GC). One main compound with retention time exactly matching (Z)-3-hexenal accumulated in the gas phase (Fig. 4). Identification of the molecule was confirmed by mass spectrometry on the basis of typical fragmentation pattern of this hexenal isomer and its

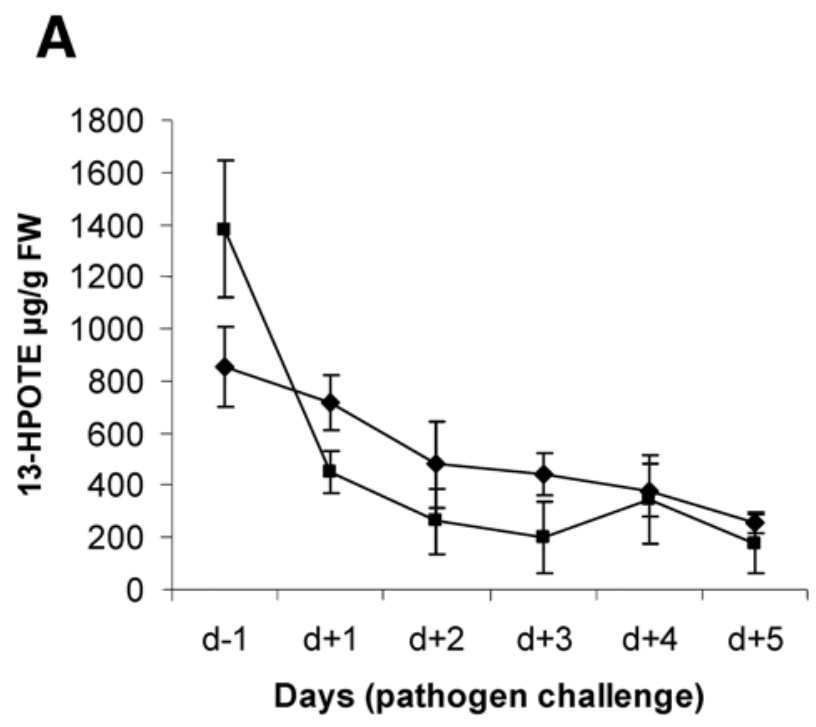

B

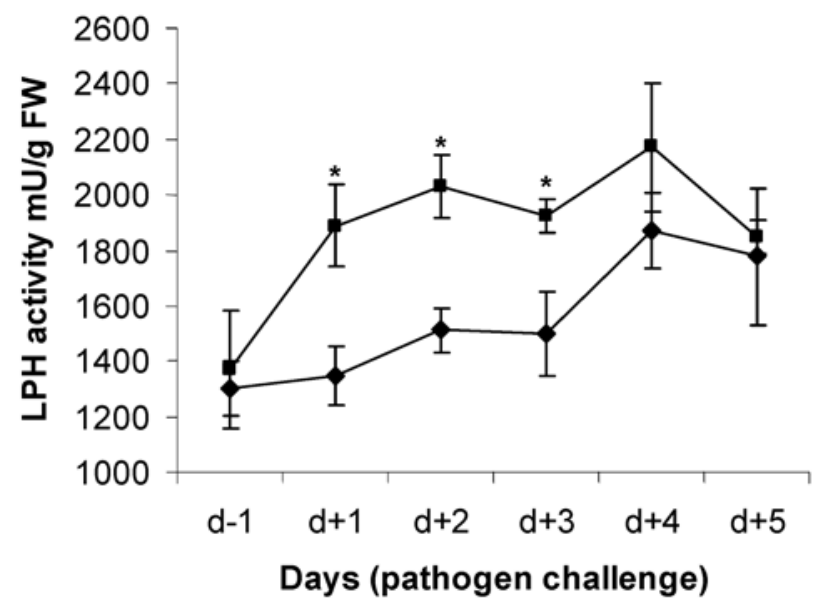

Fig. 3. Induction of lipid hydroperoxidase activity (LPH) and evolution of the 13-HPOTE (hydroperoxy-octadecadienoic acid) substrate concentration in bean plants previously treated with Pseudomonas putida BTP1 ( $)$ and in control plants ( ). Extracts for both determinations were prepared from the first true leaves collected just before inoculation of the pathogen and $24(\mathrm{~d}+1), 48(\mathrm{~d}+2), 72(\mathrm{~d}+3), 96(\mathrm{~d}+4)$, and $120 \mathrm{~h}$ $(d+5)$ after challenge. A, Concentration of the 13-hydroperoxide was determined by high-performance liquid chromatography after extraction with hexane/ethyl ether. Data are means and standard deviations calculated from three measurements performed at every sampling time in three independent experiments. B, LPH activity represents the activity of all hydroperoxide-degrading enzymes and was determined spectrophotometrically by monitoring hydroperoxide decomposition at $234 \mathrm{~nm}$. Enzyme extracts were prepared from leaf material used for endogenous hydroperoxide concentration analyses. Data are means and standard errors of four independent experiments with three measurements performed on leaf material collected at every sampling time in every experiment. Data were normally distributed, and the homogeneity of variances was verified according to the Levene's test $(P=0.05) . *$ indicates significant differences $(\alpha=0.05)$ in HPL activity between controls and BTP1-treated plants at a specific timepoint, as revealed by pair-wise comparison of means with the Fisher's least significant difference test. molecular ion size. GC-mass spectrometry (MS) analysis also revealed the concomitant formation of 12-oxo-(Z)-9-dodecenoic acid, the other product of 13-HPOTE- $\alpha$-scission mediated by the activity of hydroperoxide lyase (HPL) (data not shown). Besides (Z)-3-hexenal, only small amounts of hexen1-ol, directly formed from the aldehyde hexanal through the action of alcohol dehydrogenase, were detected as other HPLderived volatile products.

HS-GC analyses of LHP products showed that the amounts of (Z)-3-hexenal generated during the 5-min incubation time were similar to the amounts of hydroperoxides consumed over the same period, as determined spectrophotometrically. This was observed in both $P$. putida BTP1-treated and control plants at day 2 or 3 postinfection in two separate experiments (Table 1). These data are consistent with HPL accounting for essentially all 13-HPOTE-degrading activity present in these leaf extracts. (Z)-3-hexenal production was about $1,350 \mathrm{nmol}$ per min per $\mathrm{g}$ of $\mathrm{FW}$ and is in the same range as values of 1,300 and 3,000 nmol per min per $\mathrm{g}$ of FW HPL activity reported for potato (Vancanneyt et al. 2001) and tomato leaves, respectively (Fauconnier et al. 1997). Moreover, HPLC analyses at various wavelengths and GC-MS performed after methylation of reaction products did not identify any other compound that could be generated by the various HPOTE-degrading enzyme activities over the 15 -min reaction time (data not shown). Incidentally, no LHP activity was observed at any time in tissue extracts containing cytosolic enzymes.

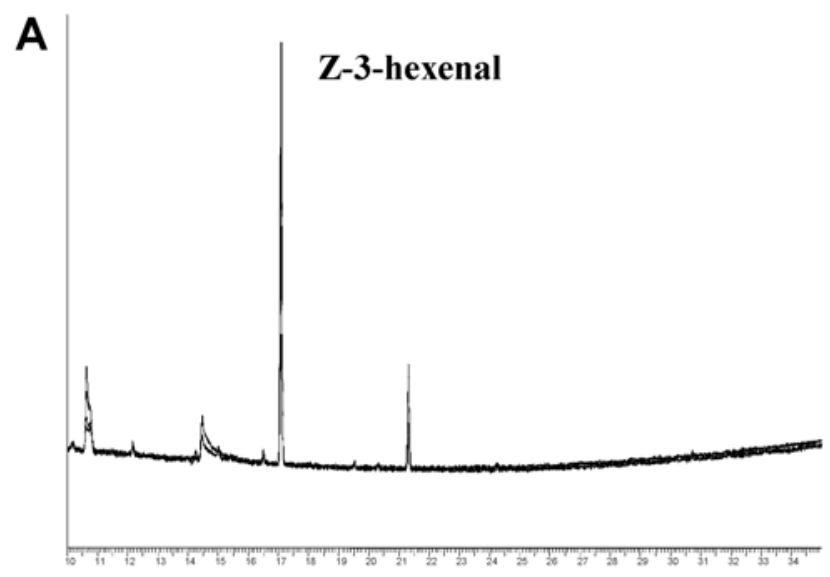

B

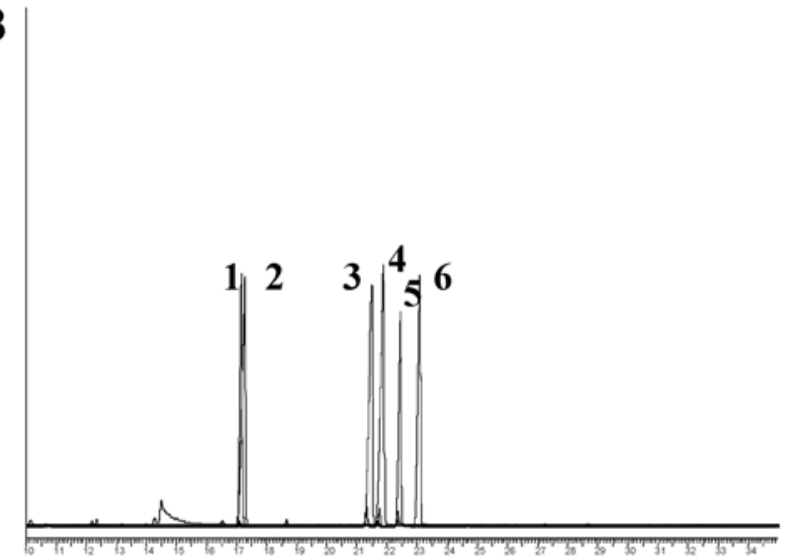

Fig. 4. Typical headspace-gas chromatography profile resulting from the $\mathbf{A}$, analysis of volatile aldehydes present in bean leaves compared to the B, chromatogram obtained for analysis of a mixture of standards: 1, z-3hexenal; 2, E-2-hexenal; 3, hexen-1-ol; 4, E-3-hexenol; 5, Z-3-hexenol; 6, E-2-hexenol. 
Accumulation of hexenal in PGPR-treated plants.

HPL thus appeared to be highly active in bean leaves, and we therefore evaluated the abundance of HPL-derived volatile aldehydes in these infected tissues by HS-GC. Although traces of (E)-2-hexenal, (E)-2-hexenol, and two other unidentified volatile aldehydes were also detected; co-chromatography with authentic standards and GC-MS analyses revealed that the 13-HPOTE-derived metabolite (Z)-3-hexenal was again the major derivative (data not shown). Root treatment with $P$. putida BTP1 also resulted in a transient increase in the amount of (Z)-3-hexenal in bean leaves. Concentrations of this $\mathrm{C}_{6}$-aldehyde were similar in control and BTP1-treated plants, before infection with $B$. cinerea. However, during the first two days after pathogen challenge, significantly higher concentrations were observed in leaves of plants inoculated with BTP1 (Fig. 5). After $48 \mathrm{~h}$, this aldehyde accumulated to 25 nmoles per $\mathrm{g}$ of FW in treated beans, an increase of about $40 \%$ as compared with control plants.

Table 1. HPL and LPH activities in bean leaves treated or not treated with Pseudomonas putida BTP1

\begin{tabular}{lcc}
\hline Type of plant $^{\mathbf{a}}$ & $\begin{array}{c}\text { Z-3-hexenal produced } \\
(\mathbf{n m o l} / \mathbf{m i n})^{\mathbf{b}}\end{array}$ & $\begin{array}{c}\text { 13-HPOTE consumed } \\
(\mathbf{n m o l} / \mathbf{m i n})^{\mathbf{c}}\end{array}$ \\
\hline Control (2) & $110 \pm 12^{\mathrm{d}}$ & $106 \pm 17$ \\
BTP1-treated (2) & $243 \pm 26$ & $247 \pm 40$ \\
Control (3) & $153 \pm 17$ & $170 \pm 43$ \\
BTP1-treated (3) & $336 \pm 37$ & $354 \pm 56$ \\
\hline
\end{tabular}

${ }^{\mathrm{a}}$ Followed by the number of days after pathogen challenge. Assays were realized on tissues from the first true leaves collected 48 or $72 \mathrm{~h}$ after pathogen challenge.

${ }^{\mathrm{b}}$ Represents hydroperoxide lyase activity (HPL) activity based on the direct analysis of formed aldehydes by headspace-gas chromatography.

${ }^{c}$ Represents lipid hydroperoxidase activity (LPH) activity based on the spectrophotometric measurement of hydroperoxide decomposition of absorbance at $234 \mathrm{~nm}$. HPOTE = hydroperoxy-octadecadienoic acid.

${ }^{\mathrm{d}}$ Mean \pm standard error of three replicates per treatment.

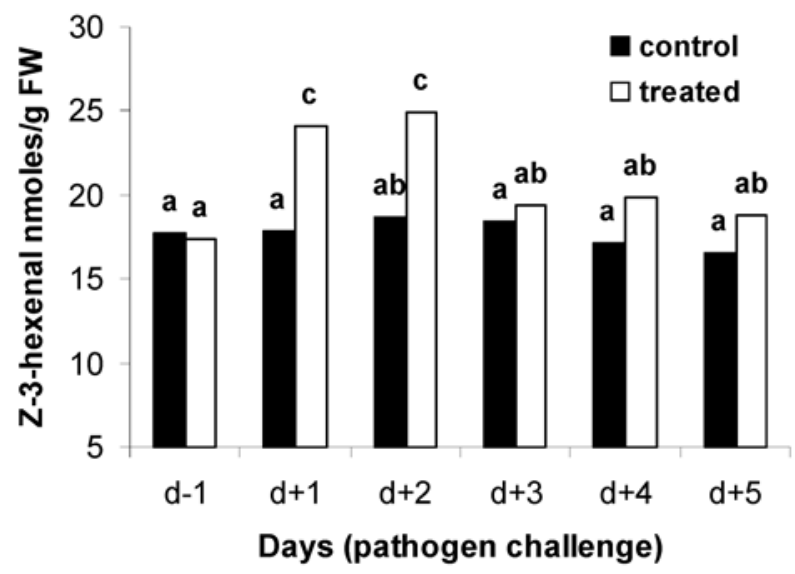

Fig. 5. Evolution of endogenous Z-3-hexenal concentrations in bean leaves from control and BTP1-treated plants before pathogen inoculation (d-1) and $24(\mathrm{~d}+1), 48(\mathrm{~d}+2), 72(\mathrm{~d}+3), 96(\mathrm{~d}+4)$, and $120 \mathrm{~h}(\mathrm{~d}+5)$ following the challenge. Z-3-hexenal was analyzed by headspace-gas chromatography in infected leaf samples randomly collected in each treatment from three plants at every sampling time (pooled material). Data are means calculated from four independent experiments with three measurements performed on leaf material collected at every sampling time in every experiment. Data were normally distributed, and the homogeneity of variances was verified according to the Levene's test $(P=$ $0.05)$. Bars with the same letters are not significantly different $(\alpha=0.05)$, according to pair-wise comparison of means with the Fisher's least significant difference test.
ISR is not associated with endogenous SA accumulation, PAL stimulation, or higher level of phytoalexins.

Endogenous SA was assayed in leaf tissues collected two days after pathogen challenge in two separate experiments. However, no significant difference was observed in the amounts of either free or conjugated SA recovered from bacterized plants, with values of $99 \pm 60$ and 3,310 $\pm 320 \mathrm{ng}$ per $\mathrm{g}$ of FW, respectively, as compared with controls with $93 \pm 56$ and 2,910 $\pm 510 \mathrm{ng}$ per $\mathrm{g}$ of $\mathrm{FW}$, respectively.

We also examined whether PAL activity could actually be stimulated in plants bacterized with $P$. putida. Globally, no clear differences were observed between treated and control plants before infection and during the first 5 days after pathogen challenge (Fig. 6). A transient increase was noted at day 3 postinfection, but it is difficult to associate such a limited stimulation with any metabolic change leading to a strong and durable defense response.

In an attempt to correlate the protective effect observed upon treatment with $P$. putida BTP1 with specific accumulation of antifungal compounds in bean plant tissues, methanolic extracts from infected and noninfected leaves were analyzed for their fungitoxic activity. The extraction procedure recovers typical bean phytoalexins such as phaseolin, phaseolidin, and phaseolinisoflavan (Hynes et al. 1994). No marked fungitoxicity could be visualized at any time in extracts from either BTP1-treated plants or control plants, either in thin-layer chromatography bioassay against Cladosporium cucumerinum or in agar diffusion-based tests for growth inhibition of $B$. cinerea (data not shown).

\section{DISCUSSION}

Our results demonstrate that treatment of bean roots with Pseudomonas strain BTP1 conferred some decreased susceptibility against gray mold caused by $B$. cinerea. This disease reduction was clearly associated with the stimulation of the activities of two key enzymes involved in the LOX pathway, i.e., lipoxygenase and hydroperoxide lyase. LOX activity appeared to be enhanced in noninfected plants following PGPR treatment, but higher levels were also maintained for 2 days after challenge with the pathogen. At this time, no apparent tissue necrosis or

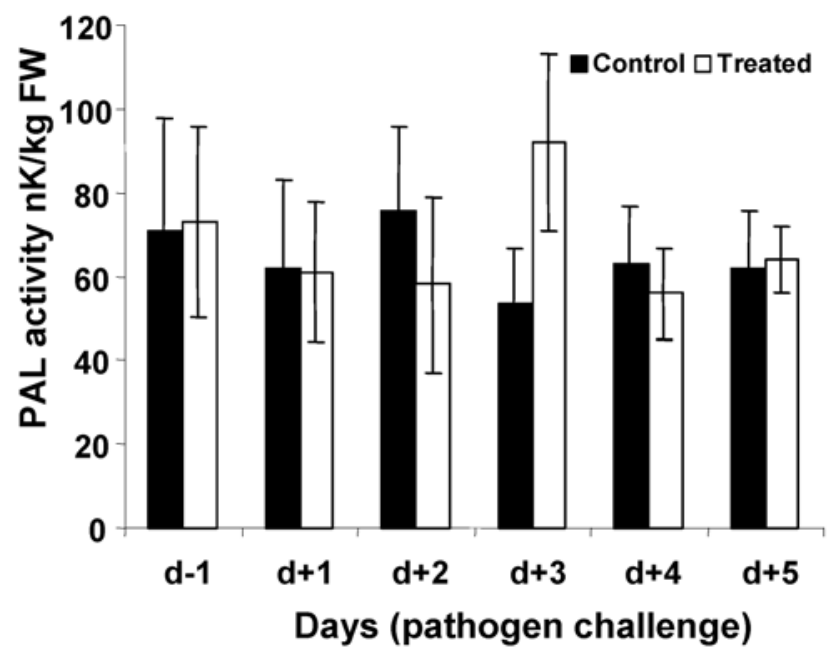

Fig. 6. Time course evolution of phenylalanine ammonia-lyase (PAL) activity in leaves of bean plants treated or not treated with Pseudomonas putida BTP1. PAL activity measurements were performed on infected leaf material collected $24(\mathrm{~d}+1), 48(\mathrm{~d}+2), 72(\mathrm{~d}+3), 96(\mathrm{~d}+4)$, and $120 \mathrm{~h}(\mathrm{~d}+5)$ after pathogen challenge or just before infection (d-1). Data are means and standard deviations calculated from two measurements of samples collected at every timepoint in two independent experiments. 
typical symptoms associated with hypersensitive cell death could be visualized on leaves. This suggests that the observed LOX induction did not rely on any wounding response phenomenon, nor was it associated to some hypersensitive response development, as demonstrated in incompatible plant-pathogen interactions (Montillet et al. 2002). The increased lipid peroxidation observed before infection, illustrated by both higher LOX activity levels and higher concentrations of endogenous hydroperoxides, thus appeared to be specifically induced upon perception of $P$. putida BTP1 by root cells.

In contrast to LOX, similar hydroperoxide lyase activities were observed in both BTP1-treated and control bean plants before infection. However, the activity of this enzyme appeared to be significantly enhanced in plants inoculated with BTP1 in the first $24 \mathrm{~h}$ following infection with the pathogen. This early HPL stimulation may explain why no accumulation of endogenous hydroperoxides could be observed at any time postinfection, despite higher LOX levels in BTP1-treated plants. As a result of enhanced HPL activity, significantly higher amounts of Z-3-hexenal were found in leaves from BTP1-treated plants compared with controls during the first two days after inoculation with the pathogen. These C6 aldehydes are among the most antifungal lipid-derived products generated by HPL activity, and they retain some toxicity against various fungal plant pathogens (Deng et al. 1993; Vaughn and Gardner 1993). Hexenal concentrations in leaves from control plants did not vary significantly over the sampling time and were seemingly not sufficient to readily inhibit pathogen ingress. However, hexenal amounts increased by $40 \%$ in BTP1-treated plants compared with controls. This differential accumulation of approximately 8 nmoles per $\mathrm{g}$ of $\mathrm{FW}$ is in the range of the quantities previously reported by Hamilton-Kemp and associates (1992) to be inhibitory to the development of $B$. cinerea. These authors showed that fungal growth was strongly impaired when spores have to germinate in an environment containing hexenal in trace amounts as low as 20 nmoles per liter of air. Moreover, in our experiments, it is possible that these values measured at the specific time of sampling in leaf tissues do not reflect the amounts that are actually produced. Previous experiments on bean have shown a very effective release of these compounds in the atmosphere at rates ranging from 5 to 20 nmoles per hour per pair of first leaves (Croft et al. 1993). With such large amounts being lost from leaves, it seems fair to assume that the quantities effectively produced at sources within the leaf tissues might be in the range that could locally (e.g., in the intercellular spaces) restrict hyphal penetration of Botrytis. These molecules could, therefore, play a role as "volatile" phytoalexins, as previously suggested in the interaction of bean with Pseudomonas syringae by Croft and associates (1993).

The timing of hexenal accumulation and, more generally, of changes in the LOX pathway induced upon treatment with the bacterial strain is interesting with regard to disease development. The early accumulation of antifungal volatile products in infected leaves during the first $48 \mathrm{~h}$ after pathogen challenge most probably corresponds either to the period of spore germination, the early stage of pathogen growth, or both, leading to only few spreading lesion symptoms. Thus, it is obvious to postulate that higher levels of hexenal in treated plants could somewhat restrict this early stage of Botrytis development, as illustrated by the delay observed for the appearance of spreading lesions in BTP1-treated plants compared with controls (Fig. 1). Hamilton-Kemp and associates (1992), who reported the antifungal activity of hexenal, also used fungal spores to test the toxicity of the molecule, leading to the conclusion that hyphal reduction was mainly due to an inhibitory effect on spore germination.
Interestingly, beside their fungitoxic effect, $\mathrm{C}_{6}$-volatiles derived from the LOX pathway also have some defense-related gene-induction activity, as observed in various plants upon treatment with methyl jasmonate (Avdiushko et al. 1995). Experiments conducted on A. thaliana showed that the presence of these hexenals and associated alcohols clearly induced the activity of enzymes involved in the oxylipin pathway, i.e., LOX and AOS (Bate and Rothstein 1998). Such a positive feedback regulation of oxylipin synthesis by $\mathrm{C}_{6}$ aldehydes could also occur in BTP1-treated plants. By contrast, expression of PAL was either not stimulated or was stimulated to a much lower extent by the presence of volatiles in A. thaliana, nor was the accumulation of PR-1 and PR-2 proteins or the defense-related thionin stimulated (Bate and Rothstein 1998). This is in line with the lack of PAL induction observed in bean upon treatment with BTP1.

The stimulation of HPL and the accumulation of fungitoxic volatile products were only detected when bacterized plants were challenged with $B$. cinerea. This observation supports the concept that a signal produced by the pathogen is essential for triggering enhanced synthesis and accumulation of defense gene products (Benhamou 1996; Van Loon et al. 1998). In line with this concept, Van Peer and associates (1991) reported that enhanced phytoalexin accumulation occurred in Pseudomonas-treated carnation roots at the onset of pathogen attack. Previous studies in cucumber plants treated with BTP1 also showed a pathogen-dependant systemic accumulation of fungitoxic compounds, most probably released from a pool of conjugated phenolics (Ongena et al. 2000). Benhamou and Nicole (1999) also demonstrated that the induction of structural and biochemical cellular barriers in bacterized cucumber seedlings was much higher when roots were challenged with Pythium ultimum. Such a pathogen-dependent enhanced expression of host defense mechanisms appears to be a common feature of ISR induced by PGPR in plants.

The onset of ISR is generally not associated with major changes in gene expression, and some of the defense-related genes identified in the case of pathogen-induced SAR were not found to be up-regulated. However, some studies have associated the protective effect with specific host metabolic changes in plants developing PGPR-induced resistance. In several plant species, such as tomato (M'Piga et al. 1997), cucumber (Benhamou et al. 2000), or pea (Benhamou et al. 1996), microscopy studies have provided direct evidence for a deposition of phenolic compounds that reinforce the cell wall structure upon polymerization (lignin). These phenolics derived from the phenylpropanoid metabolism initiated by the PAL activity can also contribute to the creation of a fungitoxic environment around the sites of penetration of the pathogen. As this enzyme activity is not stimulated in BTP1-treated plants, it is unlikely that lignification plays a crucial role in the protection. Another prominent feature of SAR is the stimulation of antifungal phytoalexin synthesis (Kùc 1995). However, reports about this phenomenon and its role in PGPR-mediated ISR are still limited (Ongena et al. 2000; Van Peer et al. 1991; Zdor and Anderson 1992). As the phenylpropanoid pathway also provides precursors of isoflavonoid-derived phytoalexins in bean (Dixon et al. 2002), the lack of PAL induction upon BTP1 treatment also suggests that these compounds are not involved in plant protection provided by this bacterium. This was supported by the absence of marked fungitoxicity in methanolic extracts from both BTP1-treated plants and controls. However, in cucumber, ISR provided by BTP1 was associated with the stimulation of a systemic response based on the accumulation of antifungal phytoalexins (Ongena et al. 2000). This further exemplifies the strong heterogeneity in the nature of defense reactions inducible by one particular PGPR strain in different plant species (Benhamou et al. 1996; Van Loon et al. 1998). 
Some nonpathogenic rhizobacteria induce a SAR-type defense response associated with either endogenous free SA accumulation, PR protein expression, or both (Maurhofer et al. 1998; Timmusk and Wagner 1999). De Meyer and associates (1999a and b) also demonstrated the potential of Pseudomonas aeruginosa $7 \mathrm{NSK} 2$ derivatives to induce the SAR pathway in tobacco and bean. In these studies, induced resistance was associated with early induction of PAL activity, a major enzyme in SA synthesis (Pallas 1996), followed by an accumulation of free SA in the leaves. In our work, using the same bean-Botrytis pathosystem, P. putida BTP1 failed to initiate either any significant SA accumulation or any durable stimulation of PAL, suggesting that the resistance is SA-independent. ISR induced by BTP1 probably derives from molecular events associated with the response depending on jasmonate, synthesized from 13-hydroperoxide via the allene oxide synthase branch, and ethylene (Pieterse et al. 2001). However, HPLC analyses of leaf extracts from BTP1-treated beans did not reveal any increase in the endogenous concentrations of jasmonic acid or of its methylated form (data not shown). This is in line with previous observations suggesting that the ISR transduction pathway involves an increase in jasmonic acid sensitivity rather than an accumulation of this hormone in plant tissues (Pieterse et al 2001).

In conclusion, this study showed the ability of a nonpathogenic fluorescent Pseudomonas strain to stimulate a systemic LOX-dependent response in bean that was associated with increased protection against $B$. cinerea infection. Lipid peroxidation or subsequent reactions, or both, leading to the synthesis of oxylipins were demonstrated to be involved in defense and stress reactions and are inducible by various physical, chemical, and biotic factors (Blée 2002). To our knowledge, this work provides the first example of a selective induction of LOX and HPL enzymes as a response to treatment with PGPR. We hypothesize the sequential activation of these two key enzymes by root preinoculation with BTP1. The bacterium sensitized bean plants to react more efficiently to subsequent pathogen infection. This led to the accumulation of antifungal volatile products that could act locally to restrict pathogen ingress. However, hexenal accumulation should be considered as one component of the bean response. There is a multitude of oxylipins derived from other branches of the LOX pathway that display various biological activities and, thus, could play crucial roles in the plant defense process. By analogy with the pathogen-induced SAR, macroscopic disease reduction triggered by PGPR treatment may result from a biochemically complex and multicomponent response leading to the concomitant stimulation of several defense mechanisms with additive effects. Whether some other plant responses, such as production of lytic enzymes with antifungal activities or plant cell wall reinforcement, are stimulated or not in bean elicited by strain BTP1 remains to be elucidated.

\section{MATERIALS AND METHODS}

\section{Microbial strains.}

$P$. putida BTP1, isolated from barley roots, was originally selected for its specific features regarding pyoverdine-mediated iron transport (Jacques et al. 1995; Ongena et al. 2002b). It was maintained on Pseudomonas Agar F medium (Becton, Dickinson and Company, Le pont de Claix, France) at $4^{\circ} \mathrm{C}$, before experimental use and was stored at $-80^{\circ} \mathrm{C}$ in cryotubes, according to manufacturer recommendations (Microbank, Prolab Diagnostic, Richmond Hill, Canada), for long-term conservation. The fungal pathogen Botrytis cinerea was provided by M. Höfte (Ghent University) (De Meyer et al. 1997). $B$. cinerea was routinely grown to sporulation on an oat-based medium (oatmeal $25 \mathrm{~g} / \mathrm{liter}$; agar $12 \mathrm{~g} / \mathrm{liter}$ ), at room temperature. For long-term storage, spores were conserved in $40 \%$ glycerol at $-70^{\circ} \mathrm{C}$.

\section{Assays for induced resistance.}

ISR assays were performed with bean (Phaseolus vulgaris) cv. Prelude, following a procedure previously described (Ongena et al. 2002a). Plants were grown either in a peat substrate (Brill Substrate GmbH \& Co KG, Georgsdorf, Germany) referred to as "soil" or in a perlite-vermiculite mix (50:50, vol/vol). Prior to planting, beans were disinfected in $\mathrm{HgCl}_{2} 0.1 \%$ for $7 \mathrm{~min}$, were rinsed three times in sterile distilled water, and were soaked for $10 \mathrm{~min}$ in a bacterial suspension at a concentration of approximately $4 \times 10^{8} \mathrm{CFU} \mathrm{ml}{ }^{-1}$ or, in the case of control plants, in $\mathrm{NaCl} 0.85 \%$. Bean seeds were then sown in $10-\mathrm{cm}$ pots containing a peat substrate (Brill Substrate $\mathrm{GmbH} \& \mathrm{Co} \mathrm{KG}$ ) compost soil or perlitevermiculite previously mixed with bacterial inoculum to a final concentration of $3 \times 10^{7} \mathrm{CFU} \mathrm{g}^{-1}$ or with an equal volume of sterile water for untreated control plants. Beans were germinated at $22 \pm 2{ }^{\circ} \mathrm{C}$ in the greenhouse with a 16 -h photoperiod. Seven and 14 days after sowing, $20 \mathrm{ml}$ of a bacterial suspension at $10^{8} \mathrm{CFU} \mathrm{ml^{-1 }}$ were added as a drench to the roots of each plant except the controls (watered with $20 \mathrm{ml}$ of $\mathrm{NaCl} 0.85 \%$ ). After approximately 20 days, bean plants were transferred to a high humidity chamber $\left(19 \pm 2^{\circ} \mathrm{C}\right)$. After 24 $\mathrm{h}$, they were leaf-infected with $B$. cinerea. To this end, eight wounds were made on both primary leaves by gently touching the epidermis with a red hot pinhead. These wounds were covered with $10 \mu \mathrm{l}$ of the pathogen spore suspension. After 4 to 5 days, the disease incidence was expressed in terms of the percentage of $B$. cinerea lesions that clearly grew out of the inoculum drop zone to produce spreading lesions. Briefly, sterilized seeds were dipped for $10 \mathrm{~min}$ in a bacterial suspension at a concentration of $4 \times 10^{8} \mathrm{CFU} / \mathrm{ml}$, prior to sowing. Bean plants were then grown in potting soil previously mixed with BTP1 cells to a final concentration of $3 \times 10^{7} \mathrm{CFU} / \mathrm{g}$. Additionally, 6 days after sowing, $20 \mathrm{ml}$ of a bacterial suspension at $10^{8} \mathrm{CFU} / \mathrm{ml}$ were added as a drench to the roots of each plant. After approximately 16 days, bean plants were transferred to a high-humidity chamber $\left(19 \pm 2^{\circ} \mathrm{C}\right)$ for $24 \mathrm{~h}$ before leaf infection with $B$. cinerea. This was achieved by inoculating each primary leaf with eight $7-\mu$ d drops of a suspension at $5 \times 10^{6}$ spores $\mathrm{ml}^{-1}$, prepared as described (Ongena et al. 2002a). In every experiment, 25 plants were used per treatment. Disease incidence was scored daily and was expressed in terms of the percentage of $B$. cinerea lesions that clearly grew out of the inoculum drop zone to produce spreading lesions. Experiments were carried out four times and contained 25 plants per treatment. For disease reduction evaluation, the homogeneity of variances was tested by ANOVA, and data from different experiments with the same set-up were pooled for mean comparison between the two treatments (least significant difference [LSD] at $\alpha=0.05$ ), as the ANOVA revealed that interaction between experiment and treatment was not significant at $P=0.05$. Means from the different treatments were compared by the method of Newman and Keuls (LSD at $\alpha=0.05$ ).

In every experiment, leaves from three plants within the same treatment were randomly harvested just before challenge with the pathogen (d-1) and $24 \mathrm{~h}(\mathrm{~d}+1), 48 \mathrm{~h}(\mathrm{~d}+2), 72 \mathrm{~h}$ $(\mathrm{d}+3), 96 \mathrm{~h}(\mathrm{~d}+4)$, and $120 \mathrm{~h}(\mathrm{~d}+5)$ after infection. At every sampling time, leaves from the three individual plants were pooled and immediately frozen in liquid nitrogen and were reduced to a fine powder with mortar and pestle. Ground leaf tissues were kept at $-25^{\circ} \mathrm{C}$ until further use for enzyme or chemical analyses. 
Measurement of salicylic acid.

Free and bound SA were extracted and measured by HPLC (Hewlett-Packard 1100 series system, Agilent Technologies, Waldbronn, Germany), following the method described by Meuwly and Métraux (1993) with some modifications. Extractions were performed on 1-g samples of ground leaf tissue obtained as described above, and leaf extract samples $(20 \mu \mathrm{l})$ were injected onto a Inertsil 5 ODS-2 $(250 \times 3 \mathrm{~mm})$ column (Varian-Chrompack, Middelburg, The Netherlands) and were eluted at a flow rate of $0.55 \mathrm{ml} / \mathrm{min}$ at room temperature. Under such conditions, SA had a retention time of $16.3 \mathrm{~min}$. It was quantified by reference to the standard curves established with commercial SA at various concentrations. SA analysis was repeated five times for each treatment, and results presented are means and standard deviations calculated from pooled data from two independent experiments.

\section{Determination of PAL activity.}

PAL activity in bean leaves was determined spectrophotometrically by measuring the conversion of L-Phe to trans-cinnamate (De Meyer et al. 1999b). Samples of leaf tissue powder were extracted with $50 \mathrm{mM}$ Tris- $\mathrm{HCl}(\mathrm{pH} 8.5)$ containing $14 \mathrm{mM}$ mercapto-ethanol and 5\% (wt/vol) polyvinylpyrollidone. Extracts were incubated for $1 \mathrm{~h}$ on ice and were homogenized by vortexing every $10 \mathrm{~min}$. Homogenates were then centrifuged $5 \mathrm{~min}$ at $13,000 \times g$ at $4^{\circ} \mathrm{C}$, and the resulting supernatants were used for PAL activity determination at $40^{\circ} \mathrm{C}$ in 3 $\mathrm{ml}$ of $50 \mathrm{mM}$ Tris- $\mathrm{HCl}(\mathrm{pH} 8.5)$ supplemented with $10 \mathrm{mM}$ phenylalanine. The evolution of the optical density at $290 \mathrm{~nm}$ was monitored with a UVIKON XS spectrophotometer (BeunDe Ronde Serlabo sa, Drogenbos, Belgium) for $1 \mathrm{~h}$, and the amount of trans-cinnamic acid generated was calculated using an $\varepsilon$ of $11,600 \mathrm{M}^{-1} \mathrm{~cm}^{-1}$. PAL activity measurements were performed twice with leaf material collected at every timepoint in two independent experiments.

\section{Antifungal activity of leaf extracts.}

Methanolic extracts of ground leaf tissues were prepared from samples consisting of $2 \mathrm{~g}$ of frozen material, as described previously (Ongena et al. 2000). Their fungitoxic activity was tested against Cladosporium cucumerinum after thin-layer chromatography on silica gel plates, based on the method of Daayf and associates (1995). In this test, zones of toxicity appear as white spots against a dark gray background that developed after fungal growth. The fungal growth inhibition potential of the leaf extracts was also tested against $B$. cinerea on plate bioassays. Aliquots $(80 \mu \mathrm{l})$ of individual extracts and of methanol (control) were dispensed in wells made in the oatbased medium. The surface was then homogeneously covered by $B$. cinerea spores by plating $100 \mu \mathrm{l}$ of a suspension at $1.5 \times$ $10^{6} \mathrm{spores} / \mathrm{ml}$. Plates were incubated at $25^{\circ} \mathrm{C}$ for 72 to $96 \mathrm{~h}$ before observation of putative growth inhibition in the zone of diffusion around the wells.

\section{Determination \\ of endogenous fatty acids and hydroperoxides.}

The procedure used for linoleic and linolenic acid extraction was adapted from the method described by Conconi and associates (1996). Samples consisting of $0.25 \mathrm{~g}$ of frozen powder prepared from control or treated plants were suspended in $1 \mathrm{ml}$ of chloroform/methanol/formic acid/water (10:10:1:1, $\mathrm{vol} / \mathrm{vol} / \mathrm{vol} / \mathrm{vol}$ ) and were stored overnight at $-20^{\circ} \mathrm{C}$. Samples were then centrifuged for $5 \mathrm{~min}$ at $13,000 \times \mathrm{g}$, and the tissue pellet was re-extracted with $1 \mathrm{ml}$ of chloroform $/ \mathrm{methanol} /$ water $(5: 5: 1, \mathrm{vol} / \mathrm{vol} / \mathrm{vol})$. After incubation for $90 \mathrm{~min}$ at $4^{\circ} \mathrm{C}$ followed by centrifugation, the two supernatants were combined and washed with $0.5 \mathrm{ml}$ of $0.2 \mathrm{M} \mathrm{H}_{3} \mathrm{PO}_{4}, 1 \mathrm{M}$
$\mathrm{KCl}$. The chloroform phase was recovered and was evaporated in a speed-vac concentrator. Fatty acids were dissolved in $200 \mu \mathrm{l}$ of hexane and were methylated by adding $0.5 \mathrm{ml}$ of $12 \%$ $\mathrm{BF} 3 / \mathrm{methanol} / \mathrm{hexane}(2.5: 55: 2, \mathrm{vol} / \mathrm{vol} / \mathrm{vol})$ at $70^{\circ} \mathrm{C}$ for $90 \mathrm{~min}$ in screw-capped tubes. Water $(400 \mu \mathrm{l})$ and hexane $(300 \mu \mathrm{l})$ were then added to $200 \mu \mathrm{l}$ of the reaction products. Fatty acid methyl esters present in the hexanic phase were separated by gas chromatography (Hewlett-Packard 5890 series II apparatus, Agilent Technologies) on a CPWAX $52 \mathrm{CB}$ column $(50 \mathrm{~m} \times 0.32 \mathrm{~mm}$, Varian-Chrompack) with flame ionization detection. The oven temperature was programmed for $5 \mathrm{~min}$ at $180^{\circ} \mathrm{C}$ followed by a $4^{\circ} \mathrm{C} \mathrm{min}^{-1}$ ramp to $220^{\circ} \mathrm{C}$ and a second ramp of $6^{\circ} \mathrm{C} \min ^{-1}$ to $250^{\circ} \mathrm{C}$ and was maintained at $250^{\circ} \mathrm{C}$ for an additional $5 \mathrm{~min}$. The methyl ester fatty acid peaks were quantified and identified by comparison of their retention times (i.e., 22.5 and $24.3 \mathrm{~min}$ for methyl linoleic acid and methyl linolenic acid, respectively) with those of commercial standards.

Hydroperoxides were extracted from leaf tissues of control and treated plants by adding $1 \mathrm{ml}$ of hexane to 0.25 -g samples of frozen tissue powder. Extracts were incubated for $90 \mathrm{~min}$ in the dark at $25^{\circ} \mathrm{C}$ before centrifugation for $5 \mathrm{~min}$ at $13,000 \times \mathrm{g}$. The pellet was then re-extracted with $1 \mathrm{ml}$ of hexane/ethyl ether $(50: 50, \mathrm{vol} / \mathrm{vol})$ under the same conditions and was centrifuged. The two supernatants were combined and evaporated to dryness under vacuum in a speed-vac concentrator. The residue was resolubilized in $200 \mu \mathrm{l}$ of methanol, and this solution was analyzed by reversed-phase HPLC (HP 1100 series system) on a LiChrospher 100 RP C-18 column $(250 \times 4.6$ $\mathrm{mm}, 5 \mu \mathrm{m}$ packing; Merck, Darmstadt, Germany), using a solvent system of acetonitrile/water/20 mM Na $\mathrm{HPO}_{4}$ at a constant flow rate of $0.7 \mathrm{ml} / \mathrm{min}$. Hydroperoxides were eluted with a gradient of acetonitrile as follows: (time in min/\% acetonitrile/\% water/\% $20 \mathrm{mM} \mathrm{Na}_{2} \mathrm{HPO}_{4}$, in volume) $0: 45: 45: 10$, $22: 45: 45: 10, \quad 42: 53: 37: 10, \quad 60: 53: 37: 10, \quad 70: 85: 5: 10$, 75:90:0:10. Absorbance at $234 \mathrm{~nm}$ indicating the conjugated diene was recorded. Under these conditions, 13-HPOTE were separated from the 9-isomers (retention time of $42.2 \mathrm{~min}$ ) and were eluted after $43.5 \mathrm{~min}$. Hydroperoxides were identified and quantified on the basis of retention times, and calibration curves were established with synthetic compounds used as standards (discussed below). The extraction product was thus used for HPL activity assays without further purification. HPOTE were quantified on the basis of absorbance at $234 \mathrm{~nm}$, using an extinction coefficient of $25,000 \mathrm{M}^{-1} \mathrm{~cm}^{-1}$.

\section{Preparation of LOX and HPL crude extracts.}

For LOX extraction, $0.5 \mathrm{~g}$ of frozen leaf tissue powder was added to $3 \mathrm{ml}$ of ice-cold $0.1 \mathrm{M}$ sodium phosphate buffer containing $0.4 \mathrm{~g} \mathrm{Na}_{2} \mathrm{~S}_{2} \mathrm{O}_{5}$ per liter and $2.5 \mathrm{~g}$ of Tween 20 per liter. This mixture was incubated for $1 \mathrm{~h}$ on ice and was homogenized by vortexing every $15 \mathrm{~min}$. It was then centrifuged for $15 \mathrm{~min}$ at $20,000 \times g$ at $4^{\circ} \mathrm{C}$, and the supernatant was used as crude extract for the LOX assay. The same procedure was applied for HPL activity extraction, except that $0.1 \%$ Triton X100 was added to the extraction buffer.

\section{LOX activity assays.}

LOX activity was determined on the basis of substrate consumption. The crude enzyme extract prepared as described above $(50 \mu \mathrm{l})$ was added to $2.940 \mathrm{ml}$ of oxygenated $0.1 \mathrm{M}$ sodium phosphate buffer, $\mathrm{pH} \mathrm{7}$, and $10 \mu \mathrm{l}$ of $18 \mathrm{mM}$ linolenic acid in $\mathrm{NaOH} 0.05 \mathrm{~N}$. The reaction was stopped by lowering the $\mathrm{pH}$ to a value of 3 with $6 \mathrm{~N} \mathrm{HCl}$ either immediately or after a 2-min incubation time at $30^{\circ} \mathrm{C}$. Aliquots $(80 \mu \mathrm{l})$ were then submitted to reverse-phase HPLC without further purification for initial and residual linolenic acid concentration measurements. Samples were injected on the LiChrospher 100 
RP C-18 column and were eluted isocratically at a constant flow rate of $1 \mathrm{ml} \mathrm{min}{ }^{-1}$ with acetonitrile/water/acetic acid 82:18:0.1 ( $\mathrm{vol} / \mathrm{vol} / \mathrm{vol})$. Under these conditions, linolenic acid eluted as a single peak after 7.9 min (UV detection at $205 \mathrm{~nm}$ ) and was quantified using calibration curves established by solubilizing various amounts of pure linolenic acid in the same sodium phosphate buffer. In every experiment, three measurements for LOX activity were realized on leaf material collected at every sampling time (discussed above). Statistical analysis was performed on pooled data from four independent experiments, using STATISTICA software (StatSoft, Inc., Maisons-Alfort, France). Data were normally distributed, and the homogeneity of variances was verified according to the Levene's test $(P=0.05)$. One-way ANOVA revealed significant differences between the treatments $(P=0.05)$, and further pair-wise comparison of means obtained for each treatment at every timepoint was realized by the Fisher's LSD test $(\alpha=$ 0.05 or 0.01 ).

\section{Substrate synthesis and HPL activity assays.}

13-HPOTE was synthesized using commercial soybean lipoxygenase and was extracted as described by Fauconnier and associates (1997). The purity of reaction products was assessed by HPLC with the method mentioned above. The extraction product was thus used for HPL activity assays without further purification. HPOTE were quantified on the basis of absorbance at $234 \mathrm{~nm}$, using an extinction coefficient of $25,000 \mathrm{M}^{-1} \mathrm{~cm}^{-1}$.

Two methods were used for the determination of HPL activity in leaves of bean plants. In the spectrophotometric assay, the activity of all hydroperoxide-degrading enzymes is determined and globally expressed as lipid hydroperoxidase activity (LHP). A typical assay consisted of $2,940 \mu \mathrm{l}$ of $0.1 \mathrm{M}$ sodium phosphate buffer, $\mathrm{pH} 6.8,7 \mu \mathrm{l}$ of $8 \mathrm{mM}$ 13-HPOTE in $\mathrm{NaOH}$ $0.05 \mathrm{~N}$, and $50 \mu \mathrm{l}$ of crude extract obtained as described above. Hydroperoxide decomposition was monitored by following the decrease in absorbance at $234 \mathrm{~nm}$ for $60 \mathrm{~s}$, and one unit of LHP activity was expressed as the amount of enzyme consuming $1 \mu \mathrm{mol}$ of 13-HPOTE in $1 \mathrm{~min}$. This method was used for measurements of HPL activity in leaf material from control and treated plants collected at the various sampling times in four independent experiments. Data set and statistical analysis were as described for LOX.

The second method is more specific for HPL activity and is based on the direct analysis of formed aldehydes by HS-GC. For this purpose, a similar enzymatic reaction was carried out in sealed 15-ml glass vials for $1 \mathrm{~min}$ and was stopped by lowering the $\mathrm{pH}$ to 3 with $12 \mathrm{~N} \mathrm{HCl}$. The vials were then transferred into an automatic headspace sampler (HS 40 XL, Perkin Elmer, Norwalk, CT, U.S.A.) and were incubated at $80^{\circ} \mathrm{C}$ for $15 \mathrm{~min}$, to allow the produced aldehydes to enter the gas phase. Volatile samples were then automatically injected onto a fused silica CP-WAX 52CB column $(50 \mathrm{~m} \times 0.32 \mathrm{~mm}$ id; Alltech Associates, Deerfield, IL, U.S.A.) in the gas chromatograph (Autosystem XL, Perkin Elmer) equipped with a flame ionization detector. Oven temperature gradient was set as follows: 0 to $5 \mathrm{~min}, 50^{\circ} \mathrm{C}$; 5 to $40 \mathrm{~min}$, from 50 to $190^{\circ} \mathrm{C}$, at a rate of $4^{\circ} \mathrm{C}$ per min. Z-3-hexenal formed was quantified by injection of various amounts of the pure compound (Fontarome Chemical, Inc., St. Francis, WI, U.S.A.). The identity of the aldehyde was confirmed by GC-MS analysis (Fauconnier et al. 2003) of a hexanic extract prepared from the reaction medium (extracted twice with $3 \mathrm{ml}$ of $\mathrm{n}$-hexane).

\section{Determination of endogenous C-6 aldehydes.}

Endogenous HPL-derived volatiles in bean were quantified from ground leaf tissue. Samples of frozen plant material $(1 \mathrm{~g})$ were placed in 12-ml headspace vials containing $3 \mathrm{ml}$ of 200 $\mathrm{mM}$ sodium phosphate buffer, previously adjusted to $\mathrm{pH} 3$ with $12 \mathrm{~N} \mathrm{HCl}$. Vials were immediately sealed and were submitted to both quantitative and qualitative analyses by HS-GC and GC-MS, respectively, as described above for the HPL assay. In every experiment and at every sampling time, three samples consisting of pooled leaf material collected from different plants, as described above, were analyzed for their hexenal content. Statistical analysis was performed on pooled data from four independent experiments, as described for LOX.

\section{ACKNOWLEDGMENTS}

This work received financial support from the Fonds National de la Recherche Scientifique (FNRS, Belgium) (Program F.R.F.C. no 2.4.570.00). We thank M. Marlier for providing technical support for mass spectrometry analyses and F. Daayf for critical reading of the manuscript.

\section{LITERATURE CITED}

Avdiushko, S., Croft, K. P. C., Brown, G. C., Jackson, D. M., HamiltonKemp, T. R., and Hildebrand, D. 1995. Effect of volatile methyl jasmonate on the oxylipin pathway in tobacco, cucumber, and Arabidopsis. Plant Physiol. 109:1227-1230.

Bate, N. J., and Rothstein, S. J. 1998. C-6-volatiles derived from the lipoxygenase pathway induce a subset of defense-related genes. Plant J. 16:561-569.

Benhamou, N., and Nicole, M. 1999. Cell biology of plant immunization against microbial infection: The potential of induced resistance in controlling plant diseases. Plant Physiol. Biochem. 37:703-719.

Benhamou, N., Kloepper, J. W., Quadt-Hallman, A., and Tuzun, S. 1996. Induction of defense-related ultrastructural modifications in pea root tissues inoculated with endophytic bacteria. Plant Physiol. 112:919-929.

Benhamou, N., Gagné, S., Le Quere, D., and Dehbi, L. 2000. Bacterialmediated induced resistance in cucumber: Beneficial effect of the endophytic bacterium Serratia plymuthica on the protection against infection by Pythium ultimum. Phytopathology 90:45-56.

Blée, E. 1998. Phytooxylipins and plant defense reactions. Prog. Lipid Res. 37:33-72.

Blée, E. 2002. Impact of phyto-oxylipins in plant defense. Trends Plant Sci. 7:315-321.

Conconi, A., Miquel, M., Browse, J. A., and Ryan, C. A. 1996. Intracellular levels of free linolenic and linoleic acids increase in tomato leaves in response to wounding. Plant Physiol. 111:797-803.

Croft, K. P. C., Juttner, F., and Slusarenko, A. J. 1993. Volatile products of the lipoxygenase pathway evolved from Phaseolus vulgaris (L.) leaves inoculated with Pseudomonas syringae pv phaseolicola. Plant Physiol. 101:13-24.

Daayf, F., Schmitt, A., and Bélanger, R. R. 1995. The effects of plant extracts of Reynoutria sachalinensis on powdery mildew development and leaf physiology of long English cucumber. Plant Dis. 79:577-580.

De Meyer, G., and Höfte, M. 1997. Salicylic acid produced by the rhizobacterium Pseudomonas aeruginosa $7 \mathrm{NSK} 2$ induces resistance to leaf infection by Botrytis cinerea on bean. Phytopathology 87:588-593.

De Meyer, G., Audenaert, K., and Höfte, M. 1999a. Pseudomonas aeruginosa 7NSK2-induced systemic resistance in tobacco depends on in planta salicylic acid accumulation but is not associated with PR1a expression. Eur. J. Plant Pathol. 105:513-517.

De Meyer, G., Capieau, K., Audenaert, K., Buchala, A., Métraux, J. P., and Höfte, M. 1999b. Nanogram amounts of salicylic acid produced by the rhizobacterium Pseudomonas aeruginosa 7NSK2 activate the systemic acquired resistance pathway in bean. Mol. Plant-Microbe Interact. 12:450-458.

Deng, W., Hamilton-Kemp, T. R., Nielsen, M. T., Andersen, R. A., Collins, G. B., and Hildebrand, D. F. 1993. Effects of six-carbon aldehydes and alcohols on bacterial proliferation. J. Agric. Food Chem. 41:506-510.

Dixon, R. A., Achnine, L., Kota, P., Liu, C. J., Reddy, M. S. S., and Wang, L. J. 2002. The phenylpropanoid pathway and plant defence-A genomics perspective. Mol. Plant Pathol. 3:371-390.

Fauconnier, M. L., Perez, A. G., Sanz, C., and Marlier, M. 1997. Purification and characterization of tomato leaf (Lycopersicon esculentum Mill.) hydroperoxide lyase. J. Agric. Food Chem. 45:4232-4236.

Fauconnier, M. L., Welti, R., Blée, E., and Marlier, M. 2003. Lipid and oxylipin profiles during aging and sprout development in potato tubers (Solanum tuberosum L.). Biochim. Biophys. Acta 1633:118-126. 
Feussner, I., and Wasternack, C. 2002. The lipoxygenase pathway. Annu. Rev. Plant Biol. 53:275-297.

Glazebrook, J., Chen, W. J., Estes, B., Chang, H. S., Nawrath, C., Métraux, J. P., Zhu, T., and Katagiri, F. 2003. Topology of the network integrating salicylate and jasmonate signal transduction derived from global expression phenotyping. Plant J. 34:217-228.

Hamilton-Kemp, T. R., McCraken, C. T., Loughrin, J. H., Andersen, R. A., and Hildebrand, D. F. 1992. Effects of some natural volatile compounds on the pathogenic fungi Alternaria alternata and Botrytis cinerea. J. Chem. Ecol. 18:1083-1091.

Hammerschmidt, R. 1999a. Induced disease resistance: How do induced plants stop pathogens? Physiol. Mol. Plant Pathol. 55:77-84.

Hammerschmidt, R. 1999b. Phytoalexins: What have we learned after 60 years? Annu. Rev. Phytopathol. 37:285-306.

Hoffland, E., Pieterse, C. M. J., Bik, L., and Van Pelt, J. A. 1995. Induced systemic resistance in radish is not associated with accumulation of pathogenesis-related proteins. Physiol. Mol. Plant Pathol. 46:309-320

Hynes, R. K., Hill, J., Reddy, M. S., and Lazarovitz, G. 1994. Phytoalexin production by wounded white bean (Phaseolus vulgaris) cotyledons and hypocotyls in response to inoculation with rhizobacteria. Can. J. Microbiol. 40:548-554.

Jacques, P., Ongena, M., Gwose, I., Seinsche, D., Schröder, H., Delfosse, P., Thonart, P., Taraz, K., and Budzikiewicz, H. 1995. Structure and characterization of isopyoverdin from Pseudomonas putida BTP1 and its relation to the biogenetic pathway leading to pyoverdines. Z. Naturforsch. C. 50:622-629.

Kloepper, J. W., Tuzun, S., and Kùc J. 1992. Proposed definitions related to induced disease resistance. Biocontrol Sci. Technol. 2:349-351.

Kohlmann, M., Bachmann, A., Weichert, H., Kolbe, A., Balkenhohl, T., Wasternack, C., and Feussner, I. 1999. Formation of lipoxygenase-pathway-derived aldehydes in barley leaves upon methyl jasmonate treatment. Eur. J. Biochem. 260:885-895.

Kombrink, E., and Schmelzer, E. 2001. The hypersensitive response and its role in local and systemic disease resistance. Eur. J. Plant Pathol. 107:69-78.

Kùc, J. 1995. Phytoalexins, stress metabolism, and disease resistance in plants. Annu. Rev. Phytopathol. 33:275-297.

Lamb, C., and Dixon, R. A. 1997. The oxidative burst in plant disease resistance. Annu. Rev. Plant Physiol. Plant Mol. Biol. 48:251-275.

Linthorst, H. J. M. 1991. Pathogenesis-related proteins of plants. Crit. Rev. Plant Sci. 10:123-150.

Maurhofer, M., Hase, C., Meuwly, P., Métraux, J. P., and Défago, G. 1994. Induction of systemic resistance of tobacco to tobacco necrosis virus by the root-colonizing Pseudomonas fluorescens strain CHA0: Influence of the gacA gene and of pyoverdine production. Phytopathology $84: 139-146$

Maurhofer, M., Reimmann, C., Schmidli-Sacherer, P., Heeb, S., Haas, D., and Defago, G. 1998. Salicylic acid biosynthetic genes expressed in Pseudomonas fluorescens strain P3 improve the induction of systemic resistance in tobacco against tobacco necrosis virus. Phytopathology 88:678-684.

Métraux, J. P. 2001. Systemic acquired resistance and salicylic acid: Current state of knowledge. Eur. J. Plant Pathol. 107:13-18.

Meuwly, P., and Métraux, J. P. 1993. Ortho-anisic acid as internal standard for the simultaneous quantitation of salicylic acid and its putative biosynthetic precursors in cucumber leaves. Anal. Biochem. 214:500-5.

Montillet, J. L., Agnel, J. P., Ponchet, M., Vailleau, F., Roby, D., and Triantaphylides, C. 2002. Lipoxygenase-mediated production of fatty acid hydroperoxides is a specific signature of the hypersensitive reaction in plants. Plant Physiol. Biochem. 40:633-639.

M'Piga, P., Bélanger, R. R., Paulitz, T. C., and Benhamou, N. 1997. Increased resistance to Fusarium oxysporum f. sp. radicis-lycopersici in tomato plants treated with the endophytic bacterium, Pseudomonas fluorescens 63-28. Physiol. Mol. Plant Pathol. 50:301-320.

Ongena, M., Daayf, F., Jacques, P., Thonart, P., Benhamou, N., Paulitz, T. C., Cornélis, P., Koedam, N., and Bélanger, R. R. 1999. Protection of cucumber against Pythium root rot by fluorescent pseudomonads: Predominant role of induced resistance over siderophores and antibiosis. Plant Pathol. 48:66-76.

Ongena, M., Daayf, F., Jacques, P., Thonart, P., Benhamou, N., Paulitz, T. C., and Bélanger, R. R. 2000. Systemic induction of phytoalexins in cucumber in response to treatments with fluorescent pseudomonads. Plant Pathol. 49:523-530.

Ongena, M., Giger, A., Jacques, P., Dommes, J., and Thonart, P. 2002a. Study of bacterial determinants involved in the induction of systemic resistance in bean by Pseudomonas putida BTP1. Eur. J. Plant Pathol. 108:187-196.

Ongena, M., Jacques, P., Delfosse, P., and Thonart, P. 2002b. Unusual traits of the pyoverdin-mediated iron acquisition system in Pseudomonas putida strain BTP1. Biometals 15:1-13.

Pallas, J., Paiva, N., Lamb, C., and Dixon, R. 1996. Tobacco plants epigenetically suppressed in phenylalanine ammonia-lyase expression do not develop systemic acquired resistance in response to infection by Tobacco mosaic virus. Plant J. 10:281-293.

Pieterse, C. M. J., Van Wees, S. C. M., Hoffland, E., Van Pelt, J. A., and Van Loon, L. C. 1996. Systemic resistance in Arabidopsis induced by biocontrol bacteria is independent of salicylic acid accumulation and pathogenesis-related gene expression. Plant Cell 8:1225-1237.

Pieterse, C. M. J., Van Pelt, J. A., Van Wees, S. C. M., Ton, J., LeonKloosterziel, K. M., Keurentjes, J. J. B., Verhagen, B. W. M., Knoester, M., Van der Sluis, I., Bakker, P., and Van Loon, L. C. 2001. Rhizobacteria-mediated induced systemic resistance: Triggering, signaling and expression. Eur. J. Plant Pathol. 107:51-61.

Ramamoorthy, V., Viswanathan, R., Raguchander, T., Prakasam, V., and Samiyappan, R. 2001. Induction of systemic resistance by plant growth promoting rhizobacteria in crop plants against pests and diseases. Crop Prot. 20:1-11.

Rancé, I., Fournier, J., and Esquerre-Tugaye, M. T. 1998. The incompatible interaction between Phytophthora parasitica var. nicotianae race 0 and tobacco is suppressed in transgenic plants expressing antisense lipoxygenase sequences. Proc. Natl. Acad. Sci. U.S.A. 95:6554-6559.

Rustérucci, C., Montillet, J. L., Agnel, J. P., Battesti, C., Alonso, B., Knoll, A., Bessoule, J. J., Etienne, P., Suty, L., Blein, J. P., and Triantaphylides, C. 1999. Involvement of lipoxygenase-dependent production of fatty acid hydroperoxides in the development of the hypersensitive cell death induced by cryptogein on tobacco leaves. J. Biol. Chem. 274:3644636455.

Sticher, L., Mauch-Mani, B., and Métraux, J. P. 1997. Systemic acquired resistance. Annu. Rev. Phytopathol. 35:235-270.

Timmusk, S., and Wagner, E. G. H. 1999. The plant-growth-promoting rhizobacterium Paenibacillus polymyxa induces changes in Arabidopsis thaliana gene expression: A possible connection between biotic and abiotic stress responses. Mol. Plant-Microbe Interact. 12:951-959.

Ton, J., De Vos, M., Robben, C., Buchala, A., Metraux, J. P., Van Loon, L. C., and Pieterse, C. M. J. 2002. Characterization of Arabidopsis enhanced disease susceptibility mutants that are affected in systemically induced resistance. Plant J. 29:11-21.

Vancanneyt, G., Sanz, C., Farmaki, T., Paneque, M., Ortego, F., Castanera, P., and Sanchez-Serrano, J. J. 2001. Hydroperoxide lyase depletion in transgenic potato plants leads to an increase in aphid performance. Proc. Natl. Acad. Sci. U.S.A 98:8139-8144.

Van Loon, L. C., and Van Strien, E. A. 1999. The families of pathogenesisrelated proteins, their activities, and comparative analysis of PR-1 type proteins. Physiol. Mol. Plant Pathol. 55:85-97.

Van Loon, L. C., Bakker, P., and Pieterse, C. M. J. 1998. Systemic resistance induced by rhizosphere bacteria. Annu. Rev. Phytopathol. 36:453483.

Van Peer, R., Niemann, G.J., and Schippers, B. 1991. Induced resistance and phytoalexin accumulation in biological control of Fusarium wilt of carnation by Pseudomonas sp. strain WCS417r. Phytopathology 81:728-734.

Vaughn, S. F., and Gardner, H. W. 1993. Lipoxygenase-derived aldehydes inhibit fungi pathogenic on soybean. J. Chem. Ecol. 19:2337-2344.

Wei, G., Kloepper, J. W., and Tuzun, S. 1996. Induced systemic resistance to cucumber diseases and increased plant growth by plant growth-promoting rhizobacteria under field conditions. Phytopathology 86:221224.

Weichert, H., Stenzel, I., Berndt, E., Wasternack, C., and Feussner, I. 1999. Metabolic profiling of oxylipins upon salicylate treatment in barley leaves-Preferential induction of the reductase pathway by salicylate. FEBS (Fed. Eur. Biochem. Soc.) Lett. 464:133-137.

Whipps, J. M. 2001. Microbial interactions and biocontrol in the rhizosphere. J. Exp. Bot. 52:487-511.

Xue, L., Charest, P. M., and Jabaji-Hare, S. H. 1998. Systemic induction of peroxidases, $1,3-\beta$-glucanases, chitinases, and resistance in bean plants by binucleate Rhizoctonia species. Phytopathology 88:359-365.

Zdor, E. R., and Anderson, A. J. 1992. Influence of root colonizing bacteria on the defence responses of bean. Plant Soil 140:99-107.

Zehnder, G. W., Murphy, J. F., Sikora, E. J., and Kloepper, J. W. 2001. Application of rhizobacteria for induced resistance. Eur. J. Plant Pathol 107:39-50. 